\title{
REGILAUL: CLEARING THE ALLITERATIVE HAZE
}

\section{Mari Sarv}

By the phrase "alliterative haze" I mean the obscuring, changing, and extending of the conventional denotation of words when they are placed in alliterating combinations. Below, I shall attempt to show how the special way of expression characteristic to parallel constructions in regilaulud (runo songs) disperses the imprecise haze of meaning that alliteration can give rise to. Furthermore, I shall observe how the meaning of words is transferred by means of alliteration and parallelism working in co-effect, and in the final part of the article I shall provide the numerical characteristics of their occurrence in the regilaulud of various regions. ${ }^{1}$

\section{1.}

We can take as a common principle for the study of poetics that different devices should be observed in co-influence. The main devices used in the regilaul (the typical metre, alliteration, parallelism and language usage regularly deviating from the colloquial) have mostly, thus far, been studied separately. A system of poetics that might be applied to regilaul is in some ways quite determined, and it should be observed as a result of a combination of its components. We might assume that one of the reasons for the long-term steadiness of Kalevala-metre folksong is a result of the combined functioning of the means of poetical system.

In regilaulud and laments the denotations words and groups of words have in ordinary language often either do not apply, or change in the contexts of alliterative and parallel constructions (e.g. adjectives can lose their specific meanings - see: Leino 1974: 121, Saarlo 1996: 103; parallel verses can be contradictory - see: Kaplinski 1997: 207 ff., Metslang 1981: 52). Above peculiarities are not, however, abnormal, but follow rather traditional and regular poetical conventions, and, apparently, have not caused misunderstanding among the users of regilaulud. So the issues we face here are how the structure of meaning of regilaulud differs from 
that of the ordinary language, and whether it is possible to argue that both alliteration and parallelism as the characteristic features of regilaul operate together in conveying the meaning of verses.

Alliteration and parallelism have been studied separately in several research papers. Their co-functioning has been addressed by Eduard Laugaste in a few pages of his doctorate thesis on alliteration in regilaul (1969: 184-188), which mainly focus on the question of whether words with a similar function and the same metrical slot alliterate similarly both in the main verse and in consecutive verses of a group of parallel verses. Wolfgang Steinitz (1934: 183) in his monograph on parallelism in the songs of Arhippa Perttunen confines himself to pointing out the importance of the relationship between alliteration and parallelism. Often discussion of the subject is limited to a mere statement that which words are chosen for use in parallel verses is solely determined by the need to alliterate (e.g. Leino 1974: 125). However, speaking about laments, Lauri Honko points out the significance of the role of parallelism for retaining the meaning of alliterating words: the reason why the idea of the sentence is not completely obscured because of this [i.e. the shifts in meaning caused by alliteration] is the continual repetition of the basic idea and the fact that the parallel expressions are recognizable as such (Honko 1974: 31).

We have to bear in mind that when a performer is following the requirements of poetic form and structure, it may not always be possible to use the most precise and adequate words in a certain context. This is why the chosen words might acquire a somewhat different meaning. By the phrase "alliterative haze" I mean the obscuring, changing, and extending of the conventional denotation of words when they are placed in alliterating combinations. Such obscuring of meaning within one verse might cause misunderstandings, but this, apparently, has not been the case with performers. On the one hand the meaning might be clearer because the traditional word combinations are already rooted in people's minds after all, it is an established poetical idiom, on the other hand, it might just be that the use of parallelism that makes the understanding easier.

Pentti Leino (1974) analyses occurrences of such alliterative haze in laments, applying the terms syntagmatic and paradigmatic (de- 
rived from Ferdinand de Saussure's and his followers') to describe relationships between linguistic units. On forming a sentence, words are combined on the syntagmatic level but selected from among expressions in paradigmatic relationship (Leino 1974: 92-93) (for example, the words combined to a sentence Jim is jogging, can be substituted with words which are in paradigmatic relationship, e.g. the rascal is running). The same terms can also be used to describe parallelism (they have been used by Helle Metslang in her works on parallelism - Metslang 1978, etc.) as paradigms which in the case of ordinary language usage remain in the hinterground of the speaker's knowledge, become expressed in the case of parallelism to a certain extent also in reality.

The nature of parallelism and its peculiarity in conveying meaning has been also treated at some length in Estonian folkloristics. On the basis of earlier research, H. Metslang (1981: 50) summarises the nature of parallelism thus: parallelism arranges subsequent verses into a whole, namely a parallel group in which the meaning of one verse and also of the form conveying it, is partly repeated, partly varied in the other parallel verses. Thus a complete meaning, a poetical picture, is formed. H. Metslang (1981: 75 ) characterises the relationships between parallel words as follows:

Referentially, parallel words or group of words either denote one referent (synonymy) or a class of referents (analogy). ${ }^{2}$ Denotatively, they are registers of elements where the performer (collective) perceives the meaningful common part (archiseme). Their basic nature is to generalise, but also to recognise the characteristics of every single detail, to find similarities considering their peculiarities.

Aino Koemets (1955: 157) provides a similar argument by means of the following example:

"Kus on orja odrapõldu, / kasupoisi kaerapõldu, / tüdruku linade põldu,/ vaeselapse viljavälja?” [Where's the beggar's barley field / the orphan's oat field / the filly's flax field / the cripple's cornfield]. By the list of individuals, we will come to think of the whole class of the outcast. The abstract generalisation is never expressed directly in parallelism, but it is clearly apparent because the single words denote the general. 
Another illustrative example of the generalisation of meaning is the use of numerals in parallel verses, whereby the exact numeral chosen is not important (though, sometimes, however, the increase or decrease in numeral is), as being one of the small or large numbers it denotes only the quantity, either small or big (cf. Laugaste 1962: 64-66).

Thus, the paradigms of parallelism in regilaulud could be distinguished from those of the ordinary language in their wider range of choices - in ordinary language a word is chosen from among those expressions or words with the same referent, the parallelism of regilaul allows for a selection from among the words and word combinations of the entire semantic area. Due to the differences between the conveying of meaning in analogic parallelism and in ordinary language, several scholars have attempted to describe the semantic mechanisms of analogic parallelism, in terms of, for example, logic - where sentences and words are in disjunctive relationships with each other (e.g. Kaplinski 1997: 205 ff.). Rephrasing it once more, we could term the most general relationship between the signifier and the signified in the analogic parallelism 'metonymic', or even 'synecdochic': one element of a parallel paradigm carries the full meaning of all the elements of the paradigm, as in the last example. In the case of synonymous parallelism, the signifiers and the signified belong to the same plane e.g. need olid kärmed ketrama, / oolsad vokki tallama [these were swift to spin/ eager to pedal the spinning wheel] - Estonian Folklore Archives: EÜS X $581(24)<$ Kullamaa (1913). And thus, the division of relations of meaning on the basis of similarity and contiguity that Roman Jakobson regards as universal (1988: 59) is expressed also in the well-known division of the parallelism of regilaul into synonymous and analogous parallelism.

Finding common synonyms for a word is relatively complicated; the selection of choice is much bigger in case of poetical synonyms and words belonging to the semantic area of a larger group of words (and their possible synonyms), and therefore their fitting into alliterative combinations is much more simple. Secondly, if the semantic whole is formed by the elements of parallel verses which function similarly, the meaning of single words does not have to be specifically determined. Therefore, the widespread use of alliteration is possible when the semantic area of single words is extended. 
In the end, comprehension of the verses comes at the level of the parallel group, and the hazy denotation of single words (when compared to the ordinary use of language) is neither relevant nor troubling.

In discussions of the classical form of regilaul, central emphasis is laid on the conformity of verses with the so-called 'quantity rules'. In Baltic-Finnic folklore, however, alliteration and parallelism occur also elsewhere: for instance, in laments and the old Setu folk songs, neither of which employs the regular classical Kalevala metre. According to Pentti Leino, the Estonian regilaul systematically deviates from the classical Kalevala metre (Leino 1986: 135). In his other works he questions whether these rules have ever applied to Estonian regilaul at all (Leino 1994: 71). The constraint of using short stressed syllable at the rise of the foot according to the quantity rules was apparently more strictly applied only in one part of Estonia and often it can be detected only while reconstructing the verse (system). W. Anderson, for example, argues that in regilaulud from Kolga-Jaani, the disyllabic words in the middle of verse which begin at the fall of the foot, often start with an irregularly long first syllable (Anderson 1935: 194). The most common notion of regilaul is concerned both with Kalevala metre in its traditional form and its vaguely definable Estonian counterpart, and is therefore far more dispersed. Due to the metrical variety of the songs which clearly belong to the same genre with songs in classical Kalevala-metre, the only proper way to categorise these songs has to involve consideration of their other characteristic features. And this will expand the notion of regilaul even more (from that of the simple notion of 'a song in Kalevala metre') because these features are significant also in fields and genres in which the traditional metre occurs less frequently. Kristi Salve argues that both alliteration and parallelism are far more important as features which allow one to regard certain songs as being regilaulud, than the metre established by quantity rules (Salve 1997: $475 \mathrm{ff}$.). Though definitions of regilaulud often focus on metrical rules, even commonly available study materials classify folk songs such as children's songs, onomatopoetic songs, magic chants, laments, under the regilaul-type, even though their metre is not generally in accordance with the rules (Laugaste 1977: 125). 
Repetition is usually considered to be the earlier form of parallelism (see e.g. Kuusi 1963: 135). In the songs of the Ob-Ugrians (see e.g. Lintrop 1997-1998) and of the Lapps often only a single word is varied in parallel verses. Perhaps such repetition was later changed to a preference for alliteration - and in order to extend the choice of alliteratives, more than one word has to change. In the long verses of Karelian laments some words are repeated from one verse to another, other words, however, form parallel paradigms which alliterate from verse to verse (see e.g. Leino 1974: 119). The parallel verses of Mordvin folk songs include, besides frequent repetition, more than one changing parallel word, their alliteration being coincidental (see The Great Bear, Mordwinische Volksdichtung). There is nothing extraordinary about that, since in the Mordvin languages the stress had moved from the first syllable as early as in the Proto-Mordvin (Korhonen 1994: 78-79). More amazing are the few alliterated distichs in longer parallel verses (can they be remnants from earlier periods?) which are extremely simi-

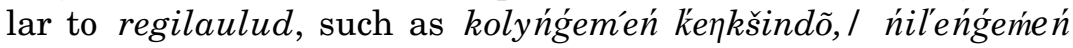
ńežendõ 'thirty gates, forty bolts' (The Great Bear: 488).

After the metre of regilaul became fixed as an octosyllabic metre, there was no more space for extensive repetitions. The words repeated for artistic reasons at the (supposed) earlier stage of parallelism were then discarded, in connection with the now-established verse-length and the alteration of parallelism. This was rendered possible by ellipsis characteristic to ordinary language. Two-paradigm parallel groups (see Metslang 1978: 119) are prevalent apparently due to partiality to alliteration. (In regilaul verses two words (not three, nor more) alliterate most often - see the figures below.) Another important factor has been the quantity of verse, which has allowed neither more paradigms nor repetitions. Matti Kuusi (1983: $191 \mathrm{ff}$.) has pointed out the bigger relative importance of sound and word repetitions in parallel verses of the southern region of regilaul (Estonia, Ingria and the isthmus of Karelia see Virtanen 1987: 18). Kuusi argues that the classical Kalevalametre is concerned with purely semantic parallelism, whereas the version found in southern regions involves, rather, semantic-phonological parallelism. And as was the case with the non-classical nature of metre, we might ask whether this is a late-evolving feature, or whether it is a remnant from an earlier period. Neverthe- 
less, it appears that it is caused mainly by the shortening of languages and also by the more frequent use of more than two syllables in verse feet (see Anderson 1935: 196 ff., Leino 1982: 329). These tendencies have increased the number of words in verse that, along with alliteration, has allowed a more extensive use of repetition.

It is difficult to determine how universal or widespread such cowork between alliteration and parallelism might be. Some peoples whose folklore includes parallelism never uses alliteration only because the word stress in their language is not on the first syllable, which seems to be one of the relevant preconditions for using alliteration. Nevertheless, in the lore of, say, the Mongolian and Turkic languages both alliteration and parallelism function as an organising factor of folk poetry (Žirmunski 1974, Kudiarov 1984: 26). Apparently, the joint application of alliteration and parallelism by Baltic-Finnic people was much more common and was known to them earlier than the Kalevala-metre (see e.g. Tedre 1959: 84). At the times of intensive oral culture, such poetic method might have been used in every-day language besides short forms of folklore not necessarily belonging to a specific folkloric genre. An example here could be an extract from the text of a fairytale where nad tõivad põhjatu palju põtru, lõpmata palju lindusid ja arvamata ulk anisid kodu [they brought home a number of elks, an infinite number of fowl and geese] - Estonian Folklore Archives: H II 29, $565(1)$ < Tartu-Maarja (1890). Even in a today's news broadcast about the closing of bigger road near the state border in South Estonia, a Setu woman uttered a complaint in between the ordinary news text: saa-ai tiid pite tulla, saa-ai asvalti pite astu [Cannot come along the road, cannot walk along the asphalt].

Besides the use of alliterative-parallel combinations in regilaulud, they are also used in an intriguing way in the poetry of a wellknown Estonian poet Artur Alliksaar. If, in case of regilaul, it is impossible to determine which is of primary importance - alliteration or parallelism, then in Alliksaar-like poetry (see Krull 1998: 787) one of the principal constitutional means of poetic expression is euphony and thus also alliteration. Alliteration as well as any other kind of euphony is often expressed in parallel verses (e.g. Kõik jääb ladusalt lünklikuks. / Kõik jääb korrapäraselt katkendlikuks [All stays easily episodic./All stays duly desultory] -Alliksaar 
1997: 237), whereas the main reason for using this technique is certainly not imitating regilaulud, ${ }^{3}$ but the use of parallel verse seems to be in some way caused by a wish to employ euphony. Any kind of euphony (a various repetition of sounds and similar syllabic structures) might run either vertically or horizontally if parallel verses are placed above one other (öö on täis tärkamise teravaid ja närbumise nukraid lõhnu - [The night is filled with acrid fumes of germination and gloomy fumes of withering] - ibid. p. 284). In a certain way the result of finding the alliterative parallels in regilaulud is as pleasant as what has been said about the poetry of Alliksaar: In the language the poet does not search for means to express the possible contents more perfectly, but he searches for a way to express the language itself with the maximum possible amplitude (Krull 1998: 777).

Similarly to the development of the language and metre of regilaul, parallelism and alliteration are inseparably interrelated. The historical development presented here shows that the use of alliteration and parallelism as such has in all probability formed in their mutual co-operation, and has supposedly become a method of transferring meaning, systematically different from the ordinary language and, also, an aesthetically-satisfying one.

2.

The discussion above might seem to some to be based on mere intuition, so therefore I shall now attempt to observe the relation between alliteration and parallelism based on something more thorough.

My aim is to discover a) whether numerical figures support the assumption that there are less alliterative verses among single verses and more among the verses that belong to parallel groups and b) whether the Karelian and Ingrian songs where the quantity rules are more enforced (see Sadeniemi 1951: $43 \mathrm{ff}$.) have a closer conformity to the system of form units than, say, the West-Estonian regilaulud that are closer to the transition form.

Generally speaking, as the regilaulud collected from the same area do not differ in form at both earlier and more recent stages of collection, we can learn most clearly about their structural development from comparison of regilaulud from different regions. 
I have based my survey merely on approximately 400 verse-lines from each collection mentioned below (emphasising also the difference between lyrics and lyroepics, since this may cause differences in the use of methods of form):

1) The lyroepic songs of the Karelian singer Arhippa Perttunen (AP)

2) The lyrical songs of the Ingrian singer Larin Paraske (LP)

3) Lyroepic songs from the parishes of Jõhvi and Iisaku in Estonia (JE)

4) Lyrical songs from the parishes of Jõhvi and Iisaku (JL)

5) Lyrical songs from Kullamaa parish (KL)

The texts of the three latter collections are taken from the Estonian Folklore Archives, the songs of Arhippa Perttunen from the first volume of the scientific edition of Finnish runo-songs "Suomen Kansan Vanhat Runot" (Helsinki 1908), and the songs of Larin Paraske from the volume "Näin lauloi Larin Paraske" (Helsinki 1982).

\begin{tabular}{c|rrrrr}
$\begin{array}{c}\text { The number of alliterative } \\
\text { words in a verse }\end{array}$ & AP & LP & JE & JL & KL \\
\hline 0 & & & & & \\
2 & 122 & 30 & 83 & 56 & 47 \\
3 & 244 & 282 & 251 & 237 & 218 \\
4 & 27 & 75 & 41 & 80 & 80 \\
5 & 1 & 14 & 22 & 23 & 39 \\
6 & 0 & 0 & 2 & 1 & 9 \\
7 & 0 & 0 & 0 & 0 & 1 \\
& 0 & 0 & 0 & 0 & 1
\end{tabular}

Table 1. The number of verses containing alliterative words. ${ }^{4}$

Alliteration occurs more frequently in the songs of southern region. There are, furthermore, more alliterating words, which is mostly due to the shortening of syllabic length of certain words in this region. On the other hand, lyroepic songs contain less alliteration - in case of both AP and JE the number of verses with no alliteration is larger, than the figures for lyrical songs, which are roughly similar. 


\begin{tabular}{l|rrrrr} 
& AP & LP & JE & JL & KL \\
\hline Orphan verse & 167 & 75 & 92 & 48 & 103 \\
Main verse of a parallel group & 108 & 135 & 121 & 140 & 112 \\
First post-positional verse & 108 & 135 & 121 & 140 & 112 \\
Second post-positional verse & 14 & 42 & 52 & 56 & 42 \\
Third post-positional verse & 3 & 14 & 12 & 10 & 17 \\
Further post-positional verse(s) & 0 & 0 & 1 & 3 & 9
\end{tabular}

Table 2. The categorisation of verses into parallel groups. ${ }^{\mathbf{5}}$

The number of orphan (or single) verses is larger in the songs of AP, KL and JE. The faster development of story and also the small amount of parallel verses is characteristic of both lyroepic songs as well as more recent transitional-form songs. Lyroepic songs contain less alliteration and parallelism which once again proves the interrelated dependency of these two devices. In Kullamaa songs, the categorisation is more scattered. There are a number of verses that do not belong to parallel groups, at the same time there are a number of considerably larger sets (bundles) of parallelism. The latter characteristic feature has been said to signify the stage of regilaul that has already become unstable and is quite characteristic of the West-Estonian regilaulud in general. Such long sets of parallelism could be often characterised by the repetition of the end word of a verse, which in a way marks the transition to rhyme.

\begin{tabular}{l|ccccc} 
& AP & LP & JE & JL & KL \\
\hline Orphan verse & 3,2 & 3,7 & 3,6 & 3,5 & 4,1 \\
Main verse of a parallel group & 3,0 & 3,6 & 3,6 & 3,8 & 4,2 \\
First post-positional verse & 2,6 & 3,1 & 3,1 & 3,1 & 3,7 \\
Further post-positional verse(s) & 2,4 & 2,9 & 3,1 & 2,9 & 3,7
\end{tabular}

Table 3. The average number of words in orphan verses, the main verses of parallel groups and post-positional verses.

The number of words is larger in orphan verses and in the main verses of a parallel group, than it is in the post-positional verses. This is due to the elliptic nature of the latter. It is quite obvious that the verses of Kullamaa songs include more words. LP, JE and JL are quite similar. 
AP differs from other songs in its considerably smaller number of words in verses - in Finnish and Karelian languages the words have retained their relatively longer form than in the Estonian and Ingrian languages. Wolfgang Steinitz mentions that Arhippa Perttunen is said to have lived on the language border of Finnish and North-Karelia and the language of his songs is quite close to Finnish, it also lacks several traits characteristic to Karelian language. Several suffixes that have been shortened in Karelian have retained their earlier and longer form in poetic language (Steinitz 1934: 24).

The orphan verses of AP and LP contain more words than the main verses of parallel group do, and the number of words in postpositional parallel verses is less than the number of words in the first post-positional verse. In Estonian songs, such a consistent decrease in number does not occur. However, the amount of material under consideration here is far too small to make generalisations about the intended abundance of words in the main verse of parallel group in the Estonian lyrical songs, or anything of that sort.

\begin{tabular}{l|rrrrr} 
& AP & LP & JE & JL & KL \\
\hline Orphan verse & 1,4 & 1,8 & 1,6 & 1,8 & 2,3 \\
Main verse of a parallel group & 1,6 & 2,2 & 1,9 & 2,2 & 2,3 \\
First post-positional verse & 1,4 & 2,1 & 1,9 & 2,1 & 2,3 \\
Further post-positional verse(s) & 1,7 & 2,1 & 1,7 & 1,9 & 2,1
\end{tabular}

Table 4. The average total of alliterative words in a verse.

The total of alliterative words in a verse is relatively stable. The figures are larger in the main verse of the group of parallel verse. The smaller number of alliterative words in post-positional verses could be explained by the relatively small number of words in them. As the single verse where the number of words is roughly similar with that of the main verse contains less alliterative words, we can say that use of parallelism favours the use of alliteration. Regional differences in results reflect mostly the length of words in the languages of these regions and the number of those words in verse. 


\begin{tabular}{l|rrrrr} 
& AP & LP & JE & JL & KL \\
\hline Orphan verse & 44 & 51 & 44 & 50 & 55 \\
Main verse of a parallel group & 53 & 64 & 54 & 59 & 56 \\
First post-positional verse & 55 & 70 & 63 & 67 & 62 \\
Further post-positional verse(s) & 76 & 71 & 60 & 68 & 59
\end{tabular}

Table 5. The average percentage of alliterative words in verse.

In all the samples, the relative importance of alliteration rises relative to its belonging to parallel group (in the case of JE and $\mathrm{KL}$ the figures of further parallel verses are smaller than the figures of the second parallel verse). In case of KL the differences between different verse groups are the smallest - the relation between alliteration and parallelism is relatively weak in these songs. The most significant differences between different verse groups are in the songs of AP and LP. It is clearly obvious that AP forms the further parallel verses mainly on the basis of alliterative word combinations, and also in case of LP the indicator of alliteration in all the post-positional verses of parallel groups is extremely strong.

Assuming that the relation between alliteration and parallelism is regular in the poetic system of regilaul, it is plausible that in more recent songs, belonging to the already-fallen system this relationship has become weaker. The small difference between the alliteration of parallel verses in Kullamaa songs actually proves this. The amount of alliteration, however, is not smaller, it is merely distributed more evenly. The larger number of words to a verse allows for a better choice of alliteratives, while at the same time the poetical and semantic significance of each individual word is reduced.

Thus, the relative importance of alliterative verses is stronger in the verses of parallel group. It is astonishingly apparent that in the classically-metrical songs of AP, alliteration and parallelism are more closely interrelated than in other songs: in this sense AP is followed by Larin Paraske as another popular classic. The songs from Kullamaa, which form a more recent layer of form, exhibit a relatively insignificant correlation between parallelism and alliteration. 


\section{Comments}

${ }^{1}$ I should like to put in a good word here for the workshop on alliteration at the summer seminar of Tartu NEFA in 1996, whose intriguing conversations have inspired me to write the current article (see also Saarlo 1996). At the same seminar also the term "poetical haze", previously undefined, was first used (cf. Järv 1997: 5).

Regilaul (pl. regilaulud) - the Estonian academic term for BalticFinnic Kalevala-metre folksongs (see translator's note in Sarv 1997: 105).

${ }^{2}$ In case of characteristics of parallelism we must bear in mind whether the researcher observes complete verses or merely parallel words and word combinations in parallel paradigms, and understand the popular notions synonymy and analogy accordingly.

${ }^{3}$ But also Esimese päeva erutused. / Teise päeva tujukus. / Kolmanda päeva kõhklused... [The flurry of the first day. / The moodiness of the second day. / The hesitations of the third day] -Alliksaar 1997: 202 or Saadan sulle / 10 kasteheina, / 20 karikakart, / 30 kannikest, / 40 näälikest...[I'll send you / 10 bent grasses / 20 daisies / 30 violets / 40 carnations...] - ibid. p. 288, both of them have close parallels in regilaulud.

${ }^{4}$ I have considered alliterative those words that belong to the same verse, start with the same consonant or any vowel (the letter $h$, however, has not been considered as belonging to either of these groups).

${ }^{5}$ In the current paper I have not taken into account verse-internal parallelism.

\section{References}

Alliksaar, Artur 1997. Päikesepillaja. Tartu.

Anderson, Walter 1935. Studien zur Wortsilbenstatistik der Älteren Estnischen Volkslieder. Eesti Rahvaluule Arhiivi Toimetused 2. Tartu.

Honko, Lauri 1974. Balto-Finnic Lament Poetry. Finnish Folkloristics I. Studia Fennica 17. Ed. by Pentti Leino. Helsinki, pp. 9-61. 
Jakobson, Roman 1988 [1956]. The metaphoric and metonymic poles. Modern Criticism and Theory. Ed. by D. Lodge. London and New York, pp. 57-61.

Järv, Risto 1997. Eesti usundi uurimise lähtel. Kr. J. Petersoni kommenteeritud tõlge Kr. Gananderi "Mythologia Fennicast". M.A. thesis. Manuscript available in the Library of the University of Tartu.

Kaplinski, Jaan 1997 [1972]. Parallelismist lingvisti pilguga. Võimaluste võimalikkus, pp. 205-230.

Koemets, Aino 1955. Sisu ja vormi ühtsus eesti regivärsilise rahvalaulu parallelismis. Tartu Riikliku Ülikooli toimetised. Vihik 38, pp. 145-165.

Korhonen, Mikko 1994. The Early History of the Kalevala Metre. Songs Beyond the Kalevala. Transformations of Oral Poetry. Studia Fennica Folkloristica 2. Ed. by Anna-Leena Siikala \& Sinikka Vakimo. Helsinki, pp. 75-87.

Krull, Hasso 1998. KaksAlliksaart. Looming nr 5, pp. 776-784.

Kudiarov, A. V. 1984. Khudozhestvenno-stilevye zakonomernosti eposa mongoloiazychnykh narodov. Fol'klor. Obraz i poeticheskoe slovo v kontekste. Red. V. M. Gatsak. Moskva, pp. 10-56.

Kuusi, Matti 1963. Varhaiskalevalainen runous. Suomen kirjallisuus I. Kirjoittamaton kirjallisuus. Toim. M. Kuusi. Helsinki, pp. 129-215.

Kuusi, Matti 1983. Maria Luukan laulut ja loitsut. Suomalaisen Kirjallisuuden Seuran toimituksia 379. Mikkeli.

Laugaste, Eduard 1962. Eesti regivärsi struktuuriküsimusi. Tartu Riikliku Ülikooli toimetised. Vihik 117, pp. 25-68.

Laugaste, Eduard 1969. Sõnaalguline ja sisealliteratsioon eesti rahvalauludes. Eesti rahvalaulu struktuur ja kujundid I. Tartu Riikliku Ülikooli toimetised. Vihik 234, pp. 3-356.

Laugaste, Eduard 1977. Eesti rahvaluule. Tallinn.

Leino, Pentti 1974. The Language of Laments. Studia Fennica 17. Finnish Folkloristics 1. Ed. by P. Leino. Helsinki, pp. 92-131.

Leino, Pentti 1982. Kieli, runo ja mitta. Suomalaisen Kirjallisuuden Seuran toimituksia 376. Pieksämäki.

Leino, Pentti 1986. Language and Metre. Studia Fennica 31. Helsinki.

Leino, Pentti 1994. The Kalevala Metre and its Development. Songs Beyond the Kalevala. Transformations of Oral Poetry. Studia 
Fennica Folkloristica 2. Ed. by Anna-Leena Siikala \& Sinikka Vakimo. Helsinki, pp. 56-74.

Lintrop, Aado 1997-1998. Palakesi obiugri mütoloogiast I-IV. Mäetagused, nr. 4, pp. 20-33, nr 5, pp. 23-33, nr 6, pp. 7-20, nr 7, pp. 7-20.

Metslang, Helle 1978. Süntaktilisi aspekte eesti regilaulu värsiparallelismis. Tallinn. Manuscript.

Metslang, Helle 1981. Eesti regilaulu värsiparallelismi lingvistilise uurimise lähtekohti. Tartu Riikliku Ülikooli toimetised $n r$ 587. Värsiõpetuse aktuaalseid probleeme ja soome-ugri värsitehnika küsimusi. Tartu, pp. 50-80.

Mordwinische Volksdichtung. Gesammelt von H. Paasonen. Herausgegeben und übersetzt von Paavo Ravila. II Band. Suomalais-ugrilaisen Seuran Toimituksia LXXXI. Helsinki 1939.

Näin lauloi Larin Paraske. Toim. Senni Timonen. Helsinki 1980.

Saarlo, Liina 1996. Varesest, sest vagast linnukesest. Vaga vares. Pro folkloristica IV. Tartu, pp. 93-103.

Sadeniemi, Matti 1951. Die Metrik des Kalevala-Verses. FFC 139. Helsinki.

Salve, Kristi 1997. Mõtteid vepsa rahvalaulust. Keel ja Kirjandus, nr 7, pp. 470-480.

Sarv, Mari 1997. Language and Poetic Metre in Regilaul. Folklore, vol. 7, pp. 87-107 (http://haldjas.folklore.ee/folklore/vol7/ maripar.htm).

Steinitz, Wolfgang 1934. Der Parallelismus in der FinnischKarelischen Volksdichtung. FFC 115. Helsinki.

Suomen Kansan Vanhat Runot I. Vienan läänin runot 1. JulkaissutA. R. Niemi. Suomalaisen Kirjallisuuden Seuran toimituksia 121, 1. Helsinki 1908.

Žirmunski, V. M. 1974. O tiurskom narodom stihe. Tiurskii geroicheskii epos. Leningrad, pp. 644-680.

Tedre, Ülo 1959. Eesti rahvalaulude tekkimisest ja arengust. Eesti rahvaluule ülevaade. Toim. R. Viidalepp. Tallinn, lk. 79-93.

The Great Bear. A Thematic Anthology of Oral Poetry in the Finno-Ugrian Languages. Lauri Honko, Senni Timonen and Michael Branch. Pieksämäki 1993.

Virtanen, Leea 1987. Suomalaisen ja virolaisen kansanrunouden suhteista. Viron veräjät. Toim. Leea Virtanen. Helsinki, pp. 13-35. 